M.-Y. SONG, ${ }^{1}$ F.-F. TIAN, ${ }^{1}$ J. DANG, ${ }^{1}$ W.-J. HUANG,,${ }^{1}$ and J.-L. GUO ${ }^{1}$

\title{
POSSIBLE ROLE OF PROTEIN CPG15 IN HIPPOCAMPAL MOSSY FIBER SPROUTING UNDER CONDITIONS OF PENTYLENETETRAZOLE KINDLING
}

\begin{abstract}
Received March 13, 2014
We examined changes in expression of the candidate plasticity-related gene 15 (CPG15) in the dentate gyrus (DG) and hippocampal CA3 region in the pentylenetetrazole (PTZ) kindling model and investigated the role of this gene in the phenomenon of mossy fiber sprouting (MFS). Experimental rats were divided into the control and PTZ groups. The epileptic model was created by intraperitoneal PTZ injection, while control rats were injected with saline. At days 3, 7, 14, 28, and 42 after the first PTZ injection, Timm staining was scored in the CA3 hippocampal area, and a product of CPG15 (protein CPG15) was labeled in the DG stratum granulosum and in the CA3 area using immunohistochemistry. The Timm scores in the CA3 region increased gradually from day 3 and were significantly higher than those in the control within the subsequent period. The level of CPG15 protein in the DG and CA3 area decreased gradually until day 14 and returned to the normal level at day 28 . The results obtained indicate, for the first time, that CPG15 may be involved in the process of MFS. Understanding the molecular mechanisms underlying this phenomenon may lead to successful therapeutic interventions that limit epileptogenesis.
\end{abstract}

Keywords: protein CPG15, mossy fiber sprouting, temporal lobe epilepsy, dentate gyrus, hippocampus.

\section{INTRODUCTION}

Epilepsy is a widespread chronic neurological disorder. Although the exact pathogenetic mechanisms of this disease remain unclear to a great extent, mossy fiber sprouting (MFS) is a pathological phenomenon observed in both animal models of temporal lobe epilepsy (TLE) and brain sections of epileptic patients [1-3]. Most studies supported the hypothesis that MFS contributes to increased seizure susceptibility by forming recurrent excitatory neuronal circuits. However, the mechanisms underlying these structural changes are not fully understood.

The hippocampal mossy fibers, axons of dentate granule cells, are normally guided to the CA3 area of the hippocampal area and form synapses with pyramidal cells. However, mossy fibers in the epileptic hippocampus abnormally innervate, due to MFS, granule cells and the molecular layer, establishing hyperexcitable recurrent circuits in the dentate gyrus (DG) [4]. Based on recent findings [5-7], MFS can

${ }^{1}$ Department of Neurology, Xiangya Hospital, Central South University, Changsha, China.

Correspondence should be addressed to F.-F. Tian

(E-mail: tianfafa@gmail.com). be regarded as a result of the disruption of molecular mechanisms underlying axonal growth and axonal guidance.

The candidate plasticity-related gene $(C P G 15)$ is the first isolated one in a screen for activity-regulated genes mediating synaptic plasticity in the rat hippocampus [8]. This gene encodes a small protein attached to the plasma membrane by its glycosylphosphatidylinositol (GPI) anchor. Protein CPG15 is a downstream target of the classic synaptic plasticity signaling cascade, which regulates axonal and dendritic arbor growth, as well as synapse maturation and neuronal survival in the CNS [911]. Since mossy fibers are axons of granule cells, it is possible that CPG15 is related to MFS in epileptogenesis via regulation of the axonal growth and synaptic plasticity.

We investigated the correctness of this hypothesis using the pentylenetetrazole (PTZ) kindling model, widely adopted as a model of synaptic rearrangement and neuronal plasticity in the epileptic brain.

\section{METHODS}

Animals and the PTZ Model. One hundred twenty adult male Sprague-Dawley rats (Animal Experimental 
Centre, Central South University, China) weighing 180 to $220 \mathrm{~g}$ were equally divided into control and PTZ groups, each containing five subgroups of 12 rats. The PTZ group received $30 \mathrm{mg} / \mathrm{kg}$ PTZ (Sigma, USA) i.p. once per day until the rats were kindled or sacrificed, while the control rats were injected with an equal volume of the solvent (saline). Rats were considered kindled when seizure attacks (score $\geq 3$ ) occurred after each PTZ injection for five consecutive days. At time points of 3, 7, 14, 28, and 42 days, after the first PTZ injection, rats were sacrificed under deep anesthesia.

Behavior Monitoring. Rats were observed for the occurrence of PTZ-induced seizures for at least 2 hours within one day before being kindled. The convulsive behavior was evaluated as previously described [12], using the following estimates: 0, no behavioral changes; 1 , facial movements, ear and whisker twitching; 2, myoclonic convulsions without rearing; 3 , myoclonic convulsions with rearing; 4, clonic convulsions with loss of posture, and 5, generalized clonicotonic seizures.

Timm Staining. At different time points, the rats were deeply anesthetized with $10 \%$ chloral hydrate and perfused intracardially with $300 \mathrm{ml}$ of saline, followed by $200 \mathrm{ml}$ of $0.1 \mathrm{M}$ phosphate buffer ( $\mathrm{pH} 7.2-7.6$ ) containing $0.4 \%$ sodium sulfide and by $200 \mathrm{ml}$ of $4 \%$ paraformaldehyde at $4{ }^{\circ} \mathrm{C}$. The brains were removed, fixed in $4 \%$ paraformaldehyde for $24 \mathrm{~h}$, transferred to $0.1 \mathrm{M}$ phosphate buffer with $30 \%$ sucrose, and finally cut into $30-\mu \mathrm{m}$-thick coronal sections.

The sections were stained in the dark for $90 \mathrm{~min}$ in a solution containing $60 \mathrm{ml}$ of $50 \%$ gum arabic, $10 \mathrm{ml}$ of $2.0 \mathrm{M}$ citrate buffer, $30 \mathrm{ml}$ of $0.5 \mathrm{M}$ hydroquinone, and $0.5 \mathrm{ml}$ of $17 \%$ silver nitrate. After washing out in water, the slides were restained with Nissl solution (Beyotime, China). After that, the slides were routinely dehydrated, cleaned, and mounted with gum. The Timm scores in the inner molecular layer (IML) and in the $C A 3$ region were estimated as previously reported [13].

Immunohistochemistry. At different time points, the rats were deeply anesthetized with $10 \%$ chloral hydrate and perfused intracardially with $300 \mathrm{ml}$ of saline and $200 \mathrm{ml}$ of $4 \%$ paraformaldehyde in $0.1 \mathrm{M}$ phosphate buffer at $4{ }^{\circ} \mathrm{C}$. The brains were removed and placed in $4 \%$ paraformaldehyde overnight, then transferred into $0.1 \mathrm{M}$ phosphate buffer containing $20 \%$ and $30 \%$ sucrose. Subsequently, $20-\mu \mathrm{m}$-thick serial sections were prepared for the analysis. The tissue sections were subjected to conventional rewarming and heat-induced antigen retrieval in $10 \mathrm{mM}$ sodium citrate buffer at the boiling point for 24 min with supplementation with cool sodium citrate buffer every $6 \mathrm{~min}$. Peroxidase and lipids were eliminated by an admixture of $1 \%$ hydrogen and methanol at $4{ }^{\circ} \mathrm{C}$ for $30 \mathrm{~min}$. After rinsing in $0.01 \mathrm{M}$ PBS, the sections were blocked using a 5\% goat serum reagent at room temperature for $2 \mathrm{~h}$ and incubated with anti-CPG15 (rabbit anti-rat polyclonal antibody, 1:50, Santa Cruz, USA) overnight at $4^{\circ} \mathrm{C}$. Then, immunohistochemistry was performed according to the kit protocol (Zhongshan Goldenbridge Tech, China). All slices were processed with a Leica DM 5000B color-image analysis system (Switzerland) for imaging and analysis; the DG and area CA3 were examined.

Statistical Analysis. Numerical data are expressed as means \pm s.d. Intergroup differences in Timm scores were compared using the Mann-Whitney U test, while intragroup differences were compared using the Kruskal-Wallis $\mathrm{H}$ test and then the Nemenyi test for pairwise comparisons. Differences among multiple groups were assessed by a one-way ANOVA, and differences between two groups were evaluated using the independent-samples $t$-test. Differences with $P<0.05$ were considered significant. All statistical analyses were performed using the Statistical package for social sciences (SPSS), version 17.0.

\section{RESULTS}

Behavioral Outcomes. With the exception of three rats that died after the development of persistent generalized clonic-tonic seizures within days 3 to 14 and one rat with no kindling developed, the remaining PTZ-treated rats manifested seizure activity of different degrees after continuous PTZ injections within days $21-28$ (average, $22.7 \pm 2.0$ days). The PTZinduced seizure activity usually occurred 5-10 min after injection and lasted 5 to $30 \mathrm{~min}$. No epileptiform activity was observed behaviorally in control rats.

Severity of MFS in the CA3 Area Correlates with Evolution of Seizure Behavior. In control rats, there was no significant difference in the Timm scores in area CA3 $(P>0.05)$ (Fig. 3). There were significant differences in these scores in the above area at each time point between the PTZ and control groups $(P<0.05)$ (Figs. 1A and 3). The degrees of MFS in the $C A 3$ were consistent with the grades of seizures in the PTZ group and reached the peak at day 28. On the other hand, the Timm scores in the IML were 0 or 1 

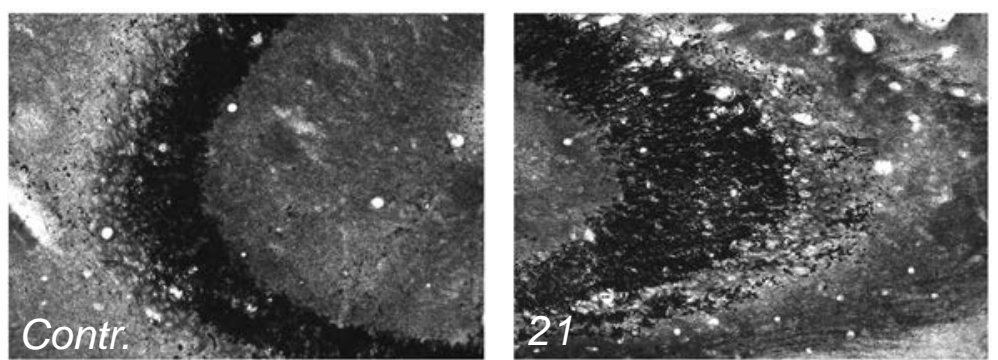

F i g. 1. Timm staining in the $C A 3$ area of control and PTZtreated rats. The intensity of Timm granules increased with the development of kindling in area CA3 in the PTZ group.

Р и с. 1. Забарвлення, за Тіммом, у зоні САЗ контрольних щурів та щурів, котрим ін'єкували пентилентетразол.
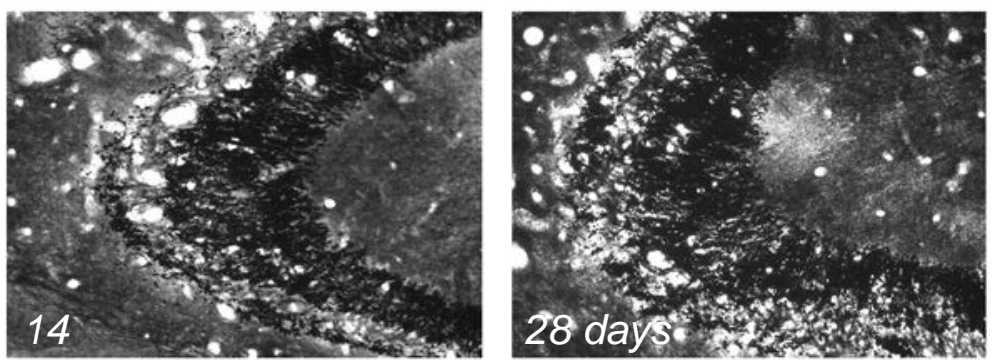

A
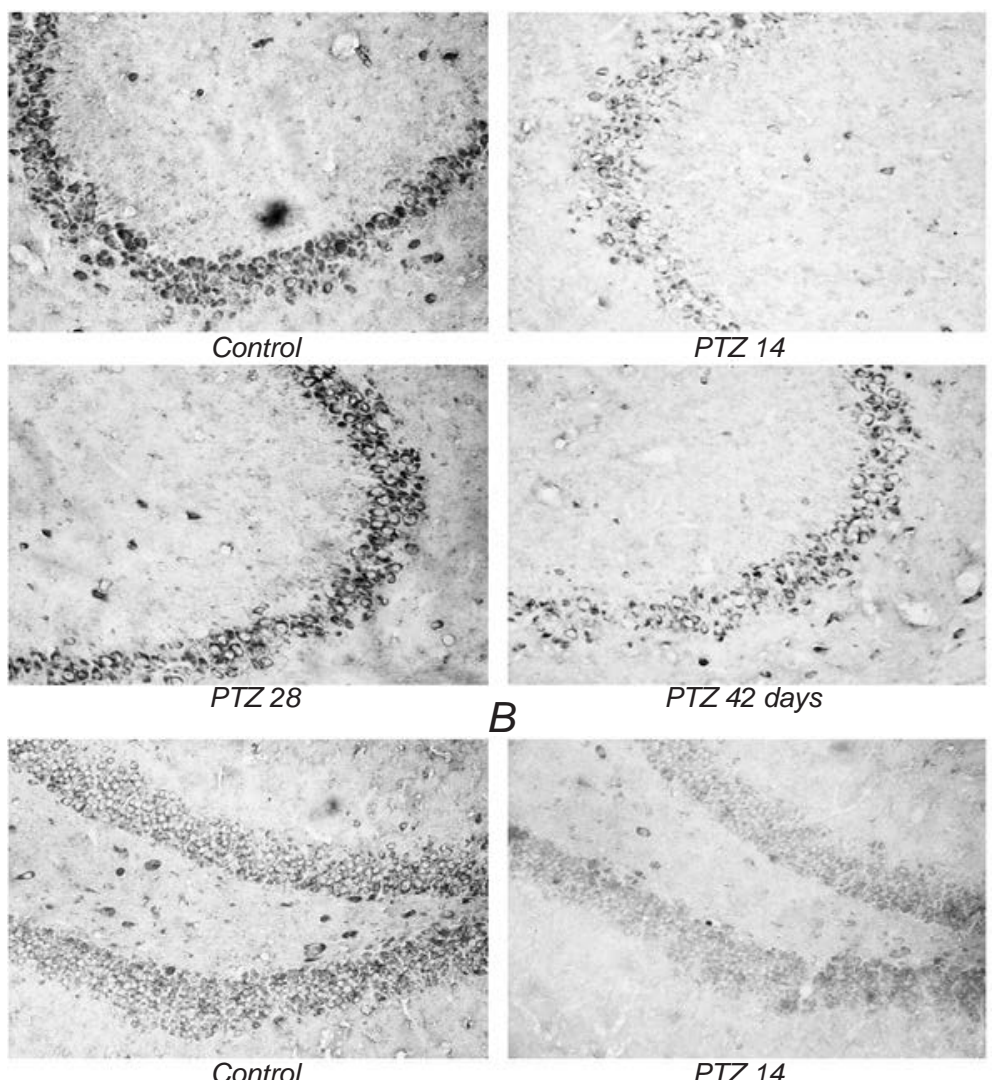

F i g.2. Expression of CPG15 in the CA3 region of the hippocampus $(A)$ and dentate gyrus $(B)$ visualized by immunohistochemistry in the control group and at different time points in the PTZ group.

Р и с. 2. Експресія протеїну CPG15 у зоні CAЗ гіпокампа $(A)$ та зубчастій звивині $(B)$ у контрольній групі та групі пентилентетразолового кіндлінгу в різні моменти часу (візуалізовано за допомогою імуногістохімічної методики).

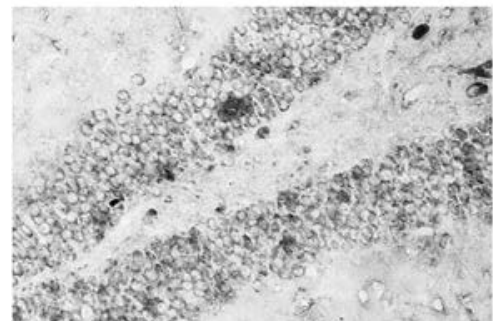

PTZ 28

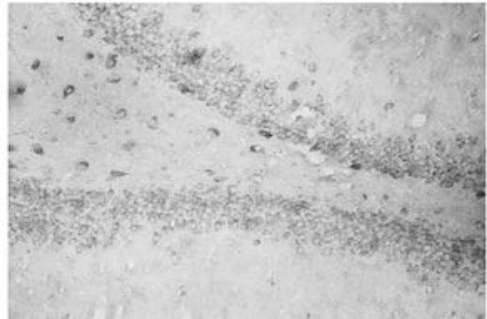

PTZ 42 days 


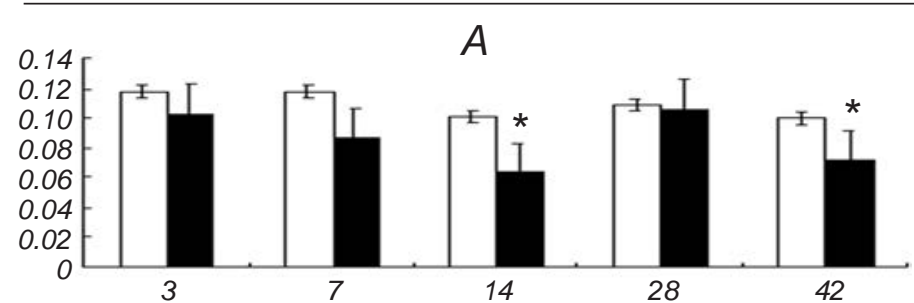

$B$

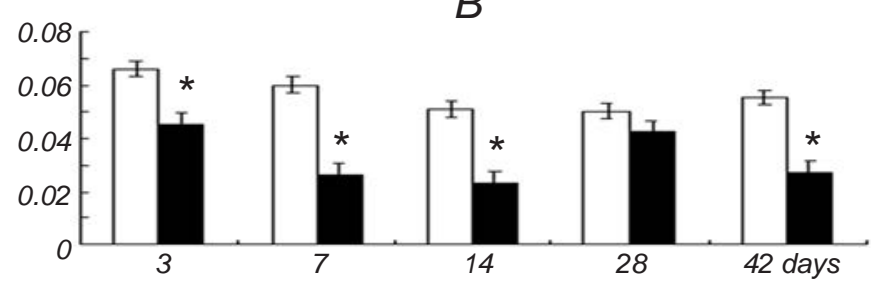

throughout the experiment in the PTZ group, with no difference with respect to the control group (data not shown).

Expression of Protein CPG15 Is Significantly Down-Regulated during PTZ Kindling Progression. The expression of CPG15 was mainly observed in the neuronal membranes within different regions of the hippocampus. Compared with the control group, the expression of CPG15 in pyramidal cells of the $C A 3$ region and in hilar neurons of the DG were significantly down-regulated $(P<0.05)$ in the PTZ group (Fig. 1 A, B and Fig. 3A, B; Table 1). This expression decreased gradually from day 3 to day 14
F i g. 3. Quantitative analysis of CPG15 protein expression in the $C A 3$ area $(A)$ and dental gyrus $(B)$. Vertical scale) Arbitrary units; horizontal scale) days after the first PTZ injection. Open and filled columns, control and PTZ groups, respectively. The data are expressed as means \pm s.d.

Р и с. 3. Кількісний аналіз експресії протеїну CPG15 у зоні CA3 $(A)$ та зубчастій звивині $(B)$.

and returned to the control level at day 28 , but downregulated again at day 42 . No obvious distinction was observed in both CA3 and DG areas among different time points in the control group (Table 2).

\section{DISCUSSION}

We examined the potential role of protein CPG15 in MFS using the PTZ kindling rat model. We found that MFS preceded the appearance of spontaneous recurrent seizures (SRSs) in such rats. The expression of protein CPG15 is in agreement with the progression of MFS.

The occurrence and development of epilepsy are usually associated with neuronal loss [14], MFS [15], and synaptic reorganization in the hippocampus. These alterations, especially MFS, are highly associated with the appearance of SRSs in humans and in epileptic animal models.

T a b l e 1. Quantitative analysis of CPG15 expression in the PTZ group.

Т а б л и ц я 1. Кількісний аналіз експресії CPG15 у групі ПТ3

\begin{tabular}{c|c|c|c}
\hline Group & Time points, days & DG & CA3 \\
\hline PTZ & 3 & $0.045 \pm 0.008^{*}$ & $0.103 \pm 0.022$ \\
& 7 & $0.026 \pm 0.004^{*}$ & $0.087 \pm 0.007$ \\
& 14 & $0.023 \pm 0.003^{*}$ & $0.063 \pm 0.004^{*}$ \\
28 & $0.042 \pm 0.007$ & $0.106 \pm 0.008$ \\
& 42 & $0.027 \pm 0.003^{*}$ & $0.072 \pm 0.009^{*}$ \\
\hline
\end{tabular}

Footnote. The data are expressed as means \pm s.d.; differences from the control, $* P<0.05$

T a b l e 2. Quantitative analysis of CPG15 expression in the control group.

Т а б л и ц я 2. Кількісний аналіз експресії CPG15 у групі контролю

\begin{tabular}{c|c|c|c}
\hline Group & Time points, days & DG & CA3 \\
\hline Control & 3 & $0.066 \pm 0.006$ & $0.118 \pm 0.009$ \\
& 7 & $0.060 \pm 0.011$ & $0.118 \pm 0.010$ \\
& 14 & $0.051 \pm 0.008$ & $0.101 \pm 0.016$ \\
& 28 & $0.055 \pm 0.002$ & $0.109 \pm 0.0003$ \\
& 42 & $0.056 \pm 0.009$ & $0.100 \pm 0.008$
\end{tabular}

Footnote. Designations are similar to those in Table 1. 
Our study demonstrated that the degree of aberrant MFS is consistent with the severity of seizures, and initiation of MFS precedes the occurrence of SRS. However, there are also some reservations. As was found in several other studies, MFS was not associated with the progression of spontaneous seizures [16, 17]. In our study, however, MFS could be observed on day 3 , i.e., before the appearance of clear SRSs, indicating that MFS is rather likely to be the cause of such seizures.

$C P G 15$ is a gene highly expressed in the nervous system; in the adult age, it is restricted to the region endowed with a high degree of plasticity, namely in the hippocampus. The expression of CPG15 protein was down-regulated gradually in the $C A 3$ area and DG region in the PTZ group. The spatial and temporal distribution consistencies of CPG15 and Timm staining supported the existence of a correlation between expression of this protein and the process of MFS. This finding, thus, suggests that CPG15 and its protein product may be significantly involved in the synaptic specificity of MFS.

Neurotrophins form a group of factors involved in nerve cell survival, proliferation, differentiation, and synaptic functions. These factors are generated by neural tissues, muscles, and astrocytes. Some studies have shown that neurotrophins are highly associated with epileptogenesis and the MFS phenomenon [18$21]$. In other studies, it was proposed that epilepsyrelated neural activity is the trigger of MFS. Protein CPG15 is a novel neurotrophin; it is a downstream target of the classic synaptic plasticity signaling cascade, involving the MAPK, CaMK, and CREB [22]. Both in vivo and in vitro studies [23] have demonstrated that CPG15 may represent a common effector of neurotrophins with respect to the neuronal activity function. Neural activity and neurotrophins induce synaptic remodeling, in particular, by altering the gene expression. Based on previous research, CPG15 can regulate axonal and dendritic arbor growth, as well as maturation of synapses and survival of neurons in the CNS. However, the mechanisms underlying the relationship between CPG15 and MFS were not investigated in our study.

In vivo studies [24] demonstrated that CPG15 protein must be attached to the plasma membrane by its GPI anchor to manifest its neurotrophic effects. GPI-anchored molecules encompass a large group of proteins of great functional diversity, including many axon-guidance molecules, such as ephrins and NCAM. These molecules are able, through contact attraction or repulsion, to regulate axonal pathfinding and growth. So, CPG15, being a GPI-anchored molecule, can, through contacts with axons, trigger a series of molecular events providing regulation of the axonal growth, pathfinding, and synaptic plasticity. Considering that CPG15 affects and regulates the above events, it should be qualified as an activityinduced signaling molecule capable of communicating between neighboring cells [25]. The receptor of CPG15 and the downstream of the above conduction pathway remain, however, unknown.

In conclusion, our study demonstrated that MFS is not the outcome of the SRS initiation. Our results indicate, for the first time, that expression of CPG15 may be involved in the development of MFS and synaptic reorganization. A throughout understanding of the molecular mechanisms underlying MFS may lead to therapeutic interventions that protect the brain from spontaneous seizures.

Acknowledgement. This work was supported by the Fundamental Research Funds for the Central Universities (Central South University, 2013zzts093).

All animals were treated humanely, and this study conformed to the guidelines for the Care and Use of Laboratory Animals published by the National Institutes of Health (NIH, Bethesda, USA). All animal-use protocols were approved by the Animal Ethics Committee of the Central South University (China).

All authors have contributed significantly and are in agreement with the content of the manuscript. The authors of this communication, M.-Y. Song, F.-F. Tian, J. Dang, W.-J. Huang, and J.-L. Guo, confirm the absense of any conflict related to comercial or financial interests, to interrelations with organizations or persons in any way involved in the research, and to interrelations of the co-authors.

М.-Ю. Сон Дж.-Л. Гуо ${ }^{1}$

МОЖЛИВА РОЛЬ ПРОТЕЇНУ СРG15 У СПРУТИНГУ МОХОВИТИХ ВОЛОКОН У ГІПОКАМПІ В УМОВАХ ПЕНТИЛЕНТЕТРАЗОЛОВОГО КІНДЛІНГУ

\author{
1 Лікарня Ксянг'я при Центральному Південному \\ університеті, Чанша (Китай). \\ P е 3 ю м е
}

Ми досліджували зміни експресії продукту гена CPG15 у зубчастій звивині (33) та зоні САЗ гіпокампа в моделі пентилентетразолового (ПТЗ-) кіндлінгу та можливу роль 
цього гена у феномені спрутингу моховитих волокон (CMB). Піддослідні щури були поділені на групи контролю та ПТЗ-кіндлінгу. Модель епілепсії створювали за допомогою внутрішньоочеревинних ін'єкцій пентилентетразолу (ПТ3); контрольним щурам ін'єкували фізіологічний розчин. На третю, сьому, 14-ту, 28-му та 42-гу добу після першої ін'єкції ПТЗ оцінювали забарвлення, за Тіммом, у зоні САЗ. Локалізацію протеїну CPG15 у stratum granulosum 33 та зоні CA3 гіпокампа визначали 3 використанням імуногістохімічної методики. Інтенсивність забарвлення, за Тіммом, у зоні САЗ поступово збільшувалася починаючи 3 третьої доби та була вірогідно вищою, ніж така в контролі, протягом усього наступного періоду. Рівень протеїну CPG15 у 33 та полі САЗ поступово зменшувався до 14-ї доби та повертався до нормальних значень на 28-му добу. Отримані результати вперше вказують на те, що CPG15 може бути залученим у процес СМВ. Зрозуміння молекулярних механізмів, на яких базується цей феномен, може призвести до розробки успішних терапевтичних заходів, котрі обмежували б епілептогенез.

\section{REFERENCES}

1. L. P. Andrade-Valenḉa, M. M. Valenḉa, T. R. Velasco, et al., "Mesial temporal lobe epilepsy: clinical and neuropathologic findings of familial and sporadic forms," Epilepsia, 6, 10461054 (2008).

2. S. R. Lamont, B. J. Stanwell, R. Hill, et al., "Ketamine pretreatment dissociates the effects of electroconvulsive stimulation on mossy fiber sprouting and cellular proliferation in the dentate gyrus," Brain Res., 1053, 27-32 (2008).

3. L. W. Kuo, C. Y. Lee, J. H. Chen, et al., "Mossy fiber sprouting in pilocarpine-induced status epilepticus rat hippocampus: a correlative study of diffusion spectrum imaging and histology," NeuroImage, 41, 789-800 (2008).

4. R. Koyama and Y. Ikegaya, "Mossy fiber sprouting as a potential therapeutic target for epilepsy," Current Neurovascul. Res., 1, No. 1, 3-10 (2004).

5. H. Lin, Y. Huang, Y. Wang, and J. Jia, "Spatiotemporal profile of $\mathrm{N}$-cadherin expression in the mossy fiber sprouting and synaptic plasticity following seizures," Mol. Cell. Biochem., 358, Nos. 1/2, 201-205 (2011).

6. A. J. Holtmaat, J. A. Gorter, J. De Wit, et al., "Transient downregulation of Sema3A mRNA in a rat model for temporal lobe epilepsy. A novel molecular event potentially contributing to mossy fiber sprouting," Exp. Neurol., 182, 142-150 (2003).

7. R. Koyama, M. K. Yamada, N. Nishiyama, et al., "Brain-derived neurotrophic factor induces hyperexcitable reentrant circuits in the dentate gyrus," J. Neurosci., 24, No. 33, 7215-7224 (2004).

8. E. Nedivi, D. Hevroni, D. Naot, et al., "Numerous candidate plasticity-related genes revealed by different cDNA cloning," Nature, 363, No. 6431, 718-722 (1993).

9. A. Javaherian and H. T. Cline, "Coordinated motor neuron axon growth and neuromuscular synaptogenesis are promoted by cpg15 in vivo," Neuron, 45, 505-512 (2005).
10. T. Fujino, J. H. Leslie, R. Eavri, et al., "CPG15 regulates synapse stability in the developing and adult brain," Genes Dev., 25, 2674-2685 (2005).

11. U. Putz, C. Harwell, and E. Nedivi, "Soluble CPG15, expressed during early development, rescues cortical progenitors from apoptosis," Nat. Neurosci., 8, 322-331(2005).

12. F. F. Tian, C. Zeng, Y. E. Ma, et al., "Potential roles of Cdk5/ p35 and tau protein in hippocampal mossy fiber sprouting in the PTZ kindling model," Clin. Lab., 56, 127-136 (2010).

13. G. L. Holmes, M. Sarkisian, Y. Ben-Ari, and N. Chevassus-AuLouis, "Mossy fiber sprouting after recurrent seizures during early development in rats," J. Comp. Neurol., 404, 537-553 (1999).

14. J. E. Cavazos and D. J. Cross, "The role of synaptic reorganization in mesial temporal lobe epilepsy," Epilepsy Behav., 8, 483-493 (2006).

15. L. H. Zeng, N. R. Rensing, and M. Wong, "The mammalian target of rapamycin signaling pathway mediates epileptogenesis in a model of temporal lobe epilepsy," J. Neurosci., 29, 69646972 (2009).

16. F. H. Lew and P. S. Buckmaster, "Is there a critical period for mossy fiber sprouting in a mouse model of temporal lobe epilepsy?" Epilepsia, 52, No. 12, 2326-2332 (2011).

17. J. Nissinen, K. Lukasiuk, and A. Pitkanen, "Is mossy fiber sprouting present at the time of the first spontaneous seizures in rat experimental temporal lobe epilepsy?" Hippocampus, 11, 299-310 (2001).

18. C. Heinrich, S. Lahteinen, F. Suzuki, et al., "Increase in BDNFmediated TrkB signaling promotes epileptogenesis in a mouse model of mesial temporal lobe epilepsy," Neurobiol. Dis., 42, No. 1, 35-47 (2011).

19. B. Paradiso, S. Zucchini, T. Su, et al., "Localized overexpression of FGF-2 and BDNF in hippocampus reduces mossy fiber sprouting and spontaneous seizures up to 4 weeks after pilocarpine-induced status epilepticus," Epilepsia, 52, No. 3, 572-578 (2011).

20. C. A. Altar, P. Laeng, L. W. Jurata, et al., "Electroconvulsive seizures regulate gene expression of distinct neurotrophic signaling pathways," J. Neurosci., 24, No. 11, 2667-2677 (2004).

21. R. M. Risbud, C. Lee, and B. E. Porter, "Neurotrophin-3 mRNA a putative target of miR2 1 following status epilepticus," Brain Res., 14, No. 24, 53-59 (2011).

22.T. Fujino, W. A. Lee, and E. Nedivi, "Regulation of cpg15 by signaling pathways that mediate synaptic plasticity," Mol. Cell Neurosci., 24, 538-554 (2003).

23. G. S. Naeve, M. Ramakrishnan, R. Kramer, et al., "Neuritin: a gene induced by neural activity and neurotrophins that promotes neuritogenesis," Proc. Natl. Acad. Sci., 94, No. 6, 2648-2653 (1997).

24. I. Cantallops and H. T. Cline, "Rapid activity-dependent delivery of the neurotrophic protein CPG15 to the axon surface of neurons in intact Xenopus tadpoles," Dev. Neurobiol., 68, No. 6, 744-759 (2008).

25. E. Nedivi, G. Y. Wu, and H. T. Cline, "Promotion of dendritic growth by CPG15, an activity-induced signaling molecule," Science, 281, No. 5384, 1863-1866 (1998). 